\title{
The effects of land-use change on arthropod richness and abundance on Santa Maria Island (Azores): unmanaged plantations favour endemic beetles
}

\author{
Seline S. Meijer • Robert J. Whittaker • \\ Paulo A. V. Borges
}

Received: 4 March 2010/Accepted: 9 August 2010/Published online: 3 September 2010

(C) Springer Science+Business Media B.V. 2010

\begin{abstract}
We study how endemic, native and introduced arthropod species richness, abundance, diversity and community composition vary between four different habitat types (native forest, exotic forest of Cryptomeria japonica, semi-natural pasture and intensive pasture) and how arthropod richness and abundance change with increasing distance from the native forest in adjacent habitat types in Santa Maria Island, the Azores. Arthropods were sampled in four $150 \mathrm{~m}$ long transects in each habitat type. Arthropods were identified to species level and classified as Azorean endemic, single-island endemic (SIE), native, or introduced. The native forest had the highest values for species richness of Azorean endemics, SIEs and natives; and also had highest values of Azorean endemic diversity (Fisher's alpha). In contrast, the intensive pasture had the lowest values for
\end{abstract}

S. S. Meijer · R. J. Whittaker

Biodiversity Research Group, Oxford University Centre

for the Environment, South Parks Road,

Oxford OX1 3QY, UK

S. S. Meijer · P. A. V. Borges ( $ه)$

Azorean Biodiversity Group (CITA-A), Departamento

de Ciências Agrárias, Universidade dos Açores, 9701-851

Terra-Chã, Angra do Heroísmo, Portugal

e-mail: pborges@uac.pt

\section{R. J. Whittaker}

Center for Macroecology, Evolution and Climate, Department of Biology, University of Copenhagen Universitetsparken 15, Copenhagen, Denmark

Present Address:

S. S. Meijer

UCD Forestry, Agriculture \& Food Science Centre,

University College Dublin, Belfield, Dublin 4, Ireland

S. S. Meijer

World Agroforestry Centre, Nairobi, Kenya endemic and native species richness and diversity, but the highest values of total arthropod abundance and introduced species richness and diversity. Arthropod community composition was significantly different between the four habitat types. In the semi-natural pasture, the number of SIE species decreased with increasing distance from the native forest, and in the exotic forest the abundance of both Azorean endemics and SIEs decreased with increasing distance from the native forest. There is a gradient of decreasing arthropod richness and abundance from the native forest to the intensive pasture. Although this study demonstrates the important role of the native forest in arthropod conservation in the Azores, it also shows that unmanaged exotic forests have provided alternative habitat suitable for some native species of forest specialist arthropods, particularly saproxylic beetles.

Keywords Arthropods - Azores · Conservation biogeography · Endemic species · Landscape matrix · Land use

\section{Introduction}

Humans are altering natural landscapes at an accelerating rate (Vitousek et al. 1997; Ramankutty and Foley 1999; Foley et al. 2005). Large-scale transformation and clearing of land have put ecosystems and biodiversity at serious risk (Tilman et al. 2001). The loss of natural habitats has led many species to become at risk of extinction (Pimm et al. 1995; Brook et al. 2003; Hanski et al. 2007) and some have claimed that habitat loss is causing a mass extinction of species (e.g. Myers 1992; Wilson 1992). Due to the timelag between habitat loss and extinction (Janzen 1986; Heywood et al. 1994), it is expected that many more 
species will go extinct in the future as a result of land conversion that has already taken place (Tilman et al. 1994; Brooks and Balmford 1996; Brooks et al. 1997, 1999a, b, 2002; Cowlishaw 1999; Grelle et al. 2005; Helm et al. 2006; Triantis et al. 2010).

As natural habitats get increasingly fragmented by human activities, it is important to understand the effects of this fragmentation on the distribution and survival of species in order to inform conservation strategies. The importance of protected areas in the conservation of biodiversity has been generally accepted (Margules and Pressey 2000; Bruner et al. 2001). This has been supported by classical ecological theories such as the theory of island biogeography (MacArthur and Wilson 1963, 1967) and metapopulation dynamics (Hanski 1998). However, these theories tend to view natural habitat patches as islands in a sea of uninhabitable matrix, which may be an unnecessarily pessimistic assumption in many cases (Bhagwat et al. 2008). As a result, the conservation of species has focussed mainly on the establishment of protected areas and the landscape outside of reserves has often been overlooked (Ricketts 2001; Whittaker and Fernández-Palacios 2007; Wiens 2007; Bhagwat et al. 2008).

Since further expansion of the existing network of protected areas might be constrained by competing claims for other land uses (Bhagwat et al. 2008) and their effectiveness in representing species diversity has been questioned (Rodrigues et al. 2004; Chape et al. 2005), it is important to start understanding which habitats besides natural vegetation can support viable populations of species. Various recent studies have examined the role of the landscape surrounding reserves and have indicated the importance of high quality matrix environments in supporting biodiversity (Gascon et al. 1999; Ricketts 2001; Vandermeer and Carvajal 2001; Hughes et al. 2002; Perfecto and Vandermeer 2002; Sekercioglu et al. 2002; Watson et al. 2005; Bhagwat et al. 2008). This switch of attention away from fragments to the matrix has been referred to as 'countryside biogeography' (Daily et al. 2001, 2003) or 'reconciliation ecology' (Rosenzweig 2003).

The Azorean archipelago has undergone drastic changes in land use since the first settlers arrived 600 years ago. Originally, the islands were covered mostly by Laurisilva forests. However, these have been reduced to small fragments restricted to higher altitudes (Borges et al. 2005a, 2006). The islands are now mainly occupied by non-native habitats, such as intensive pastures for cattle, areas for agricultural crop production, forest patches of exotic plant species, and abandoned agricultural land and pastures covered with invasive plants (Martins 1993). Since further increasing the protected area network and the area of the native forest presents many practical challenges, it is important to understand how the changes in land use have affected the Azorean biodiversity, and which habitats outside the original native forest are able to support indigenous species.

This study investigates how changes in land use have affected endemic, native and introduced arthropod richness and abundance on Santa Maria Island in the Azores. Santa Maria is the oldest island of the Azores, dating back 8.12 Myr (Abdel-Monem et al. 1975), which has resulted in higher numbers of endemic and native species compared to the other islands (Borges and Brown 1999; Borges and Hortal 2009). Arthropods were sampled using pitfall traps in four different habitat types (native forest, exotic forest, semi-natural pasture and intensive pasture) and classified as endemic (including the endemics from the target studied island, i.e. single-island-endemics-SIE), native nonendemic, or introduced. Native non-endemic species ("native" for simplicity) arrived in the Azores naturally and occur outside of the Azores as well. Introduced species are species that have been brought to the Azores by human activities. Where there was doubt over the colonisation status of a species, it was classified as native. In this study the following hypotheses will be tested: (i) species richness, abundance and diversity are highest in the native forest and lowest in the intensive pasture for Azorean endemic and native species, (ii) they are highest in the intensive pasture and lowest in the native forest for introduced species; (iii) the community composition of arthropods is different between the four habitat types; and (iv) an increase in distance to the native forest will result in a decrease in endemic, SIE and native arthropod richness and abundance in the other habitat types.

\section{Materials and methods}

\section{Study area}

This study was conducted in the Azores, an archipelago of nine islands situated in the North Atlantic (Fig. 1a). The islands are situated near the Mid-Atlantic Ridge and can be divided into three groups extending for $615 \mathrm{~km}$ : the western group (Flores and Corvo), the central group (Faial, Pico, São Jorge, Graciosa and Terceira) and the eastern group (São Miguel and Santa Maria). They are volcanic islands of recent origin, the youngest island is Pico (300,000 years) and Santa Maria is the oldest island (8.12 Myr) (Abdel-Monem et al. 1975; Borges and Hortal 2009). Santa Maria covers an area of $97 \mathrm{~km}^{2}$ and the highest point is Pico Alto, with an elevation of $587 \mathrm{~m}$. The temperate oceanic climate is strongly influenced by the proximity of the ocean and is characterised by high levels of humidity and small temperature fluctuations throughout the year. The average temperature on Santa Maria ranges between 

showing a the nine islands of the Azores. Adopted from Borges et al. (2009); and b the four habitat types on Santa Maria and the position of the 16 transects (Land-use data extracted from DROTRH 2008)
Fig. 1 Map of the region,
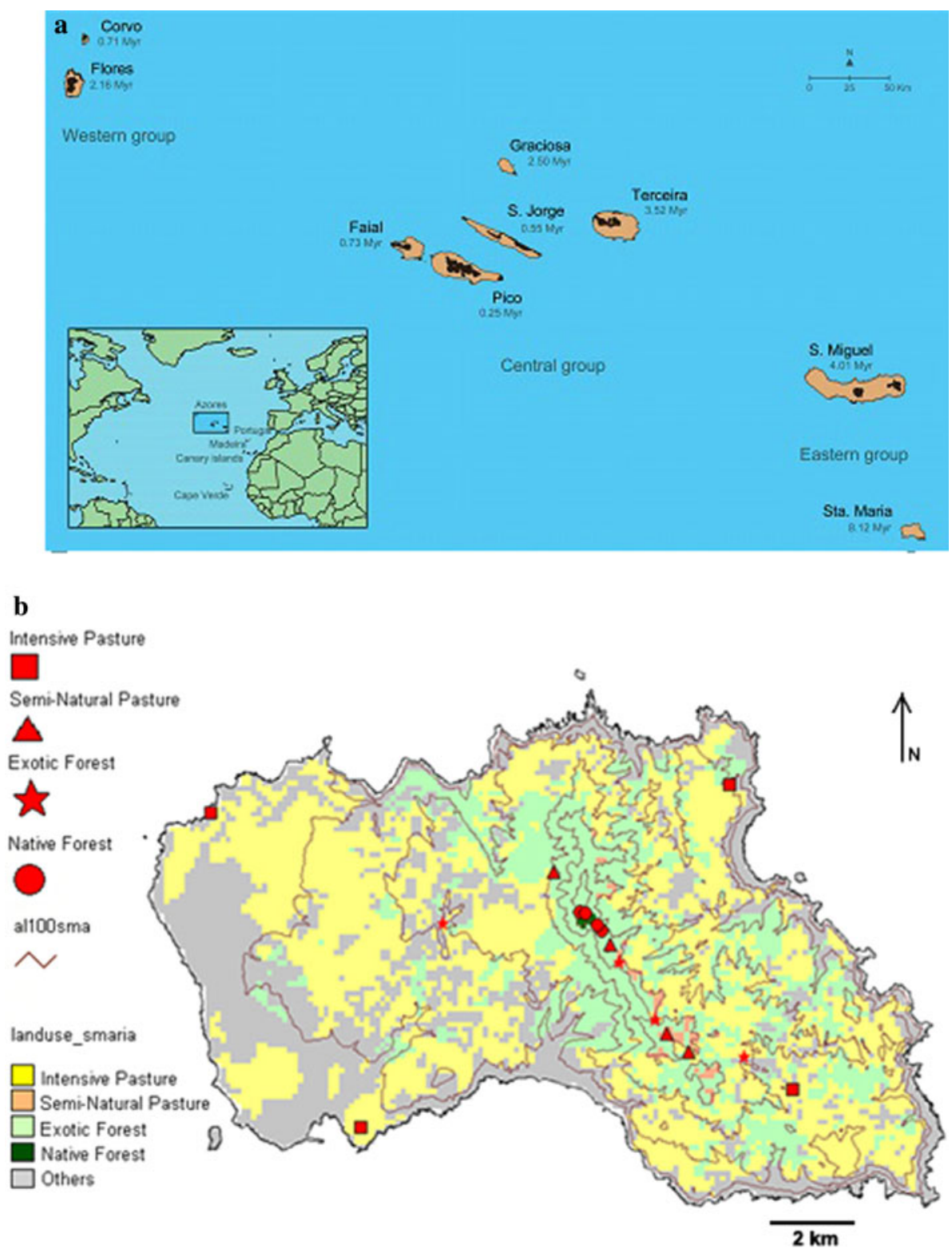

14.3 and $17.5^{\circ} \mathrm{C}$, with lowest temperatures in February and highest temperatures in August (Borges and Brown 1999). The average rainfall differs between the dry western part $\left(752 \mathrm{~mm} \mathrm{year}^{-1}\right)$ and wet eastern part $\left(1,386 \mathrm{~mm}_{\text {year }}{ }^{-1}\right)$. January and February are generally the wettest months and August the driest (Borges and Brown 1999).

The original natural vegetation of the island is Laurisilva forest, a sub-tropical evergreen broadleaf laurel type forest, which now only covers a small part of the island (Fig. 1b). The small fragment of Laurisilva forest on Santa Maria covers about 9 ha (Gaspar et al. 2008) and the overstorey consists of the broadleaf species Laurus azorica and Picconia azorica, the short-leaf species Erica azorica, and the shrub Vaccinium cylindraceum, all of them Azorean endemics. In addition, this small fragment is now being invaded by the exotic invasive plants Pittosporum undulatum and Hedychium gardneranum, which have both become abundant. The Laurisilva forests have been reduced since humans arrived on the islands in the fifteenth century. The rate of land conversion increased significantly after the Second World War, when the Government reforested parts of the islands with Cryptomeria japonica plantations and reinforced the development of cattleraising and great amounts of land were converted into pastures (Martins 1993). The vegetation on Santa Maria is now dominated by exotic forest (Cryptomeria japonica, Eucalyptus spp., Acacia spp. and Pittosporum undulatum), semi-natural pasture (not stocked year-round and with relatively low levels of fertilisation and introduced grass species) and intensive pasture (stocked year-round and with high levels of fertilisation and introduced grass and legume species). 
Site selection

On the island of Santa Maria, four sites were selected in each of the four main habitat types: native forest, exotic forest (Cryptomeria japonica plantations), semi-natural pasture and intensive pasture, resulting in a total of 16 sites (Fig. 1b). The sites were selected so as to try and sample most of the island. However, the native forest is restricted to higher elevations in the central area of the island and reduced to a 9 ha fragment, whereas the intensive pastures tend to be located at lower elevations closer to the sea. The sites in the native forest of Pico Alto were sampled in August 1997 and June 2004 (Borges et al. 2005a; Gaspar et al. 2008), and data were collected in the other three habitat types in June 2009 (Appendix 1).

\section{Arthropod sampling}

For the arthropod sampling the protocol followed since 1998 by Project BALA (see Borges et al. 2000, 2005a, Gaspar et al. 2008) was applied. At each site, 30 pitfall traps were used to capture arthropods along a transect of $150 \mathrm{~m}$ length. The pitfall traps were plastic cups with a top diameter of $42 \mathrm{~mm}$ and $78 \mathrm{~mm}$ deep. The traps were dug into the soil so that the rim of the cup was at the same level as the soil surface. Half of the traps were filled with $60 \mathrm{ml}$ of an attractive solution (Turquin) and the other half with $60 \mathrm{ml}$ of anti-freeze liquid with a small proportion of ethylene glycol. A few drops of liquid detergent were added to both solutions to reduce surface tension. A white plastic plate was placed $5 \mathrm{~cm}$ above the traps with two pieces of wire to protect the trap from rainfall. The traps were placed $5 \mathrm{~m}$ apart, starting the transect with a Turquin trap and alternating with ethylene traps. The traps were left in the field for 2 weeks and then the samples were taken to the laboratory. The specimens were sorted into morphospecies by para-taxonomists and then into species by a senior taxonomist (P. A. V. Borges). Due to non-availability of taxonomic expertise, Acari, Collembola, Hymenoptera and Diptera were excluded from this study. Based on expert opinions, the species were classified into three colonisation groups (see also Borges et al. 2005a): endemic (including the single-island endemics, or SIE), native (i.e. native but non-endemic species) and introduced species.

\section{Data analysis}

To test the first hypothesis, species richness, abundance, dominance and diversity were compared between the four habitat types (native forest, exotic forest, semi-natural pasture and intensive pasture) for Azorean endemic, native, introduced and total species. Due to the low replication of transects $(n=4)$ within each habitat type, tests of normality could not be performed and the data were analysed using non-parametric Kruskal-Wallis tests in PASW Statistics 17. In transect T07 in the semi-natural pasture, 10 pitfall traps were lost as a result of trampling by cows, and therefore the abundance numbers in each transect were converted to average abundances by dividing the total abundance in the transect by the number of pitfall traps in that transect (20 traps for T07 and 30 for all other transects). It was assumed that the 20 pitfall traps in T07 were enough to give a representative number for species richness, diversity and dominance. The Berger-Parker Index was used as a measure of dominance and Fisher's Alpha as an indicator of diversity. The total number of species expected in each habitat type was calculated using a first-order Jack-knife estimator, selected because it is considered generally robust and insensitive to scale effects (see Hortal et al. 2006). For each habitat type, the observed number of species was divided by the expected number of species to obtain a completeness index. A value above 0.75 is generally accepted as representing a complete sampling effort (see also Borges and Brown 2003). Richness and abundance data for SIEs were also analysed with Kruskal-Wallis tests. SIEs are important species for conservation purposes since they are, by definition, restricted to Santa Maria Island.

Differences in species composition between the habitat types were compared with an analysis of similarities (ANOSIM) for Azorean endemic, native, introduced and total species composition to test the second hypothesis (Clarke 1993). The $R$ statistic value ranges between 1 and -1 and indicates the degree of difference between the groups, with a value of 1 signifying completely distinct communities. Detrended correspondence analyses (DCA) were carried out to illustrate the difference in species composition between the four habitat types for each group of Azorean endemic, native, introduced and total species (Oksanen and Minchin 1997). A DCA was used to remove the arch effect that was observed when using a correspondence analysis (analysis not shown). The number of axis rescalings was four and rare species were not down-weighted. The ANOSIM and DCA were carried out in Community Analysis Package 4.0 (Henderson and Seaby 2007).

To assess the fourth hypothesis, that the increasing distance from the native forest results in a decrease in the richness and abundance of arthropod species in the adjacent habitat types, the distance to the native forest for each transect was correlated with the number of species and the number of individuals for Azorean endemic, SIE, native, introduced, and total species. The distance of each transect to the native forest was calculated using Google Maps. The intensive pastures were excluded from this analysis as they were not surrounding the native forest and were located at lower elevations. The data for the exotic forest and seminatural pasture were analysed together (eight sites) as well as 
separately (two groups of four sites). Non-parametric Spearman rank correlation (available in PASW Statistics 17) was used as the sample size was again too low to test for normality.

\section{Results}

In this study, a total of 12,513 arthropod specimens were identified to species level in the four habitat types on Santa Maria (see Appendix 2). These specimens belonged to 188 different species, of which 25 were considered endemic to the Azores (including 9 SIEs), 58 were native to the archipelago (excluding the endemics) and 105 were introduced species.

The species accumulation curves for each habitat type are starting to level off, with the intensive pastures closest to asymptote (Fig. 2a). This indicates that most of the species that occur in this habitat type have been sampled in this study, while a small number remain to be recorded in the other habitats. The same pattern can be observed for the completeness index of each habitat type, which was over or almost at the 0.75 level, indicating that about enough species were sampled to get a representative assessment of the composition and relative richness of each habitat (Appendix 3).

Species richness, abundance and diversity

Total species richness and abundance were significantly different between the four habitat types on Santa Maria (Kruskal-Wallis test, $H=8.032, P=0.045$ for species richness; $H=8.316, P=0.040$ for species abundance, Table 1). Species richness differed significantly between the four habitat types for Azorean endemics, native and introduced species (Kruskal-Wallis test, $H=12.555$, $P=0.006 ; H=10.296, P=0.016 ; H=12.192, P=0.007$, respectively). As hypothesised, Azorean endemic and native
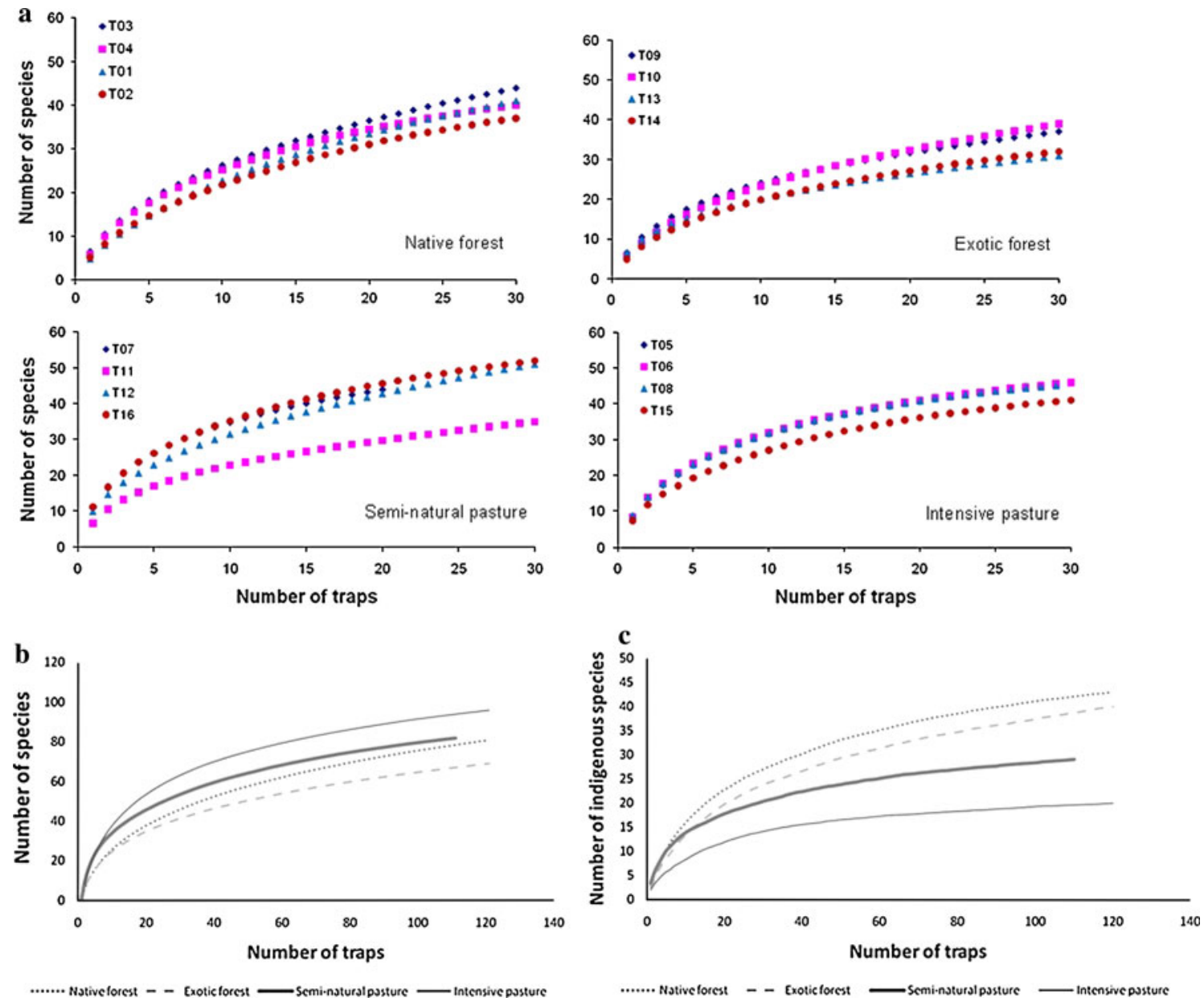

Fig. 2 Species accumulation curves, showing a curves for the total number of species (1,000 randomisations) for each transect (each containing 30 pitfall traps) per habitat type (each containing 4 transects); $\mathbf{b}$ curves for the total number of species $(1,000$

randomisations) for each habitat type (each containing 4 transects with 30 pitfall traps) and c curves for the number of indigenous species (excluding the introduced species) (1,000 randomisations) for each habitat type (each containing 4 transects with 30 pitfall traps) 
Table 1 Mean ( \pm 1 SE) richness (number of species), abundance (number of individuals), dominance (1/Berger-Parker Index) and diversity (Fisher's alpha) values for Azorean endemic, native (excluding endemics), introduced and total species for the four habitat types and results of the Kruskal-Wallis tests

\begin{tabular}{|c|c|c|c|c|c|c|c|c|}
\hline & & Native forest & Exotic forest & Semi-natural pasture & Intensive pasture & $H$ & $d f$ & $P$ \\
\hline \multirow[t]{4}{*}{ Richness } & Azorean endemic & $10.0(0.7)$ & $5.3(0.8)$ & $4.0(0.7)$ & $1.5(0.5)$ & 12.555 & 3 & 0.006 \\
\hline & Native & $15.8(0.9)$ & $14.0(1.1)$ & $13.3(1.1)$ & $7.5(0.7)$ & 10.296 & 3 & 0.016 \\
\hline & Introduced & $14.8(1.4)$ & $15.5(1.4)$ & $28.3(2.6)$ & $35.8(1.7)$ & 12.192 & 3 & 0.007 \\
\hline & Total & $40.5(1.4)$ & $34.8(1.9)$ & $45.5(3.9)$ & $44.8(1.3)$ & 8.032 & 3 & 0.045 \\
\hline \multirow[t]{4}{*}{ Abundance } & Azorean endemic & $73.5(25.0)$ & $56.5(34.6)$ & $117.3(52.1)$ & $223.0(111.0)$ & 2.713 & 3 & 0.438 \\
\hline & Native & $78.5(8.3)$ & $190.8(48.5)$ & $214.8(71.1)$ & $233.3(154.4)$ & 5.352 & 3 & 0.148 \\
\hline & Introduced & $245.3(64.8)$ & $429.8(117.0)$ & 503.8 (141.6) & $762.0(135.1)$ & 5.846 & 3 & 0.119 \\
\hline & Total & $397.3(82.7)$ & $677.0(124.3)$ & 835.8 (171.6) & $1218.3(228.5)$ & 8.316 & 3 & 0.040 \\
\hline \multirow[t]{4}{*}{ Dominance } & Azorean endemic & $2.6(0.3)$ & $1.8(0.4)$ & $1.2(0.1)$ & $0.8(0.3)$ & 10.579 & 3 & 0.014 \\
\hline & Native & $3.7(0.1)$ & $1.6(0.3)$ & $2.4(0.5)$ & $2.0(0.7)$ & 6.066 & 3 & 0.108 \\
\hline & Introduced & $2.5(0.1)$ & $2.1(0.3)$ & $3.4(0.7)$ & $3.4(0.9)$ & 4.787 & 3 & 0.188 \\
\hline & Total & $4.1(0.2)$ & $3.2(0.8)$ & $4.6(0.5)$ & $3.8(0.9)$ & 3.375 & 3 & 0.337 \\
\hline \multirow[t]{4}{*}{ Diversity } & Azorean endemic & $3.6(0.4)$ & $2.2(0.7)$ & $0.9(0.1)$ & $0.3(0.03)$ & 10.975 & 3 & 0.012 \\
\hline & Native & $6.1(0.8)$ & $3.7(0.5)$ & $3.8(0.9)$ & $2.0(0.3)$ & 11.184 & 3 & 0.011 \\
\hline & Introduced & $3.5(0.3)$ & $3.2(0.1)$ & $6.7(0.6)$ & $8.0(0.8)$ & 12.044 & 3 & 0.007 \\
\hline & Total & $11.7(0.8)$ & $8.0(0.5)$ & $10.5(0.6)$ & $9.7(1.2)$ & 7.013 & 3 & 0.071 \\
\hline
\end{tabular}

In each habitat type, four $150 \mathrm{~m}$ long transects containing 30 pitfall traps were sampled

Probabilities in bold are significant at $P<0.05$

species richness were both highest in the forest habitats (native and exotic forest) and lowest in the semi-natural and intensive pasture, while the number of introduced species was lowest in the native forest and highest in the intensive pasture (Fig. 3). Total species abundance was highest in the intensive pasture and lowest in the native forest. The same trend was apparent when the species were separated into Azorean endemic, native and introduced species (Fig. 3), although these differences were not significant.

Interestingly, when the species accumulation curves are plotted with all the species as one curve for each habitat type (Fig. 2b), the curve for the native forest comes out below that of the two pasture types. However, when the same curves are plotted for just the indigenous species (so excluding the exotic species) the native and exotic forest come out above the curves for the pastures (Fig. 2c). This indicates that the greater richness of the pasture sites is due to the non-natives and the curve levels when they are excluded.

Species dominance was significantly different between the four habitat types for Azorean endemic species (Kruskal-Wallis test, $H=10.579, P=0.014$ ), with the intensive pastures being most dominated by a few species and the native forest having the least dominance (Table 1). Species diversity was not significantly different between the four habitat types for total species richness (KruskalWallis test, $H=7.013, P=0.071$ ), but did differ significantly for Azorean endemic, native and introduced species (Kruskal-Wallis test; $H=10.975, P=0.012$ for Azorean endemic species, $H=11.184, P=0.011$ for native species; and $H=12.044, P=0.007$ for introduced species). The native forest had the highest value of Fisher's alpha for Azorean endemic and native species, and the lowest for the intensive pasture. In contrast, introduced species diversity was highest in the intensive pasture, and lower in the forest habitats (Table 1).

\section{Single-island endemics}

Of the 25 Azorean endemic species found in this study on Santa Maria, nine species are single-island endemics (SIEs), i.e. only found on Santa Maria (Table 2). The number of SIEs differed between the four habitat types (KruskalWallis test; $H=11.465, P=0.009$ ), with the highest number found in the native forest and none in the intensive pasture (Fig. 3). The abundance of the singe-island endemics was also significantly different between the four habitat types (Kruskal-Wallis test; $H=11.921, P=0.008$ ). The average abundance was highest in the native forest (Fig. 3), however, the highest abundance at transect level was recorded in one of the exotic forest transects, in which 145 individuals of the beetle Tarphius pomboi were found.

\section{Species composition}

In accordance with the third hypothesis, the total species composition of the arthropod communities was statistically different between the four habitat types (ANOSIM; 
Fig. 3 Mean ( \pm 1 SE) number of arthropod species and number of arthropod individuals per transect (four transects per habitat, each transect containing 30 pitfall traps) for Azorean endemic, native (excluding endemics), introduced and single-island endemic species found in the four habitat types
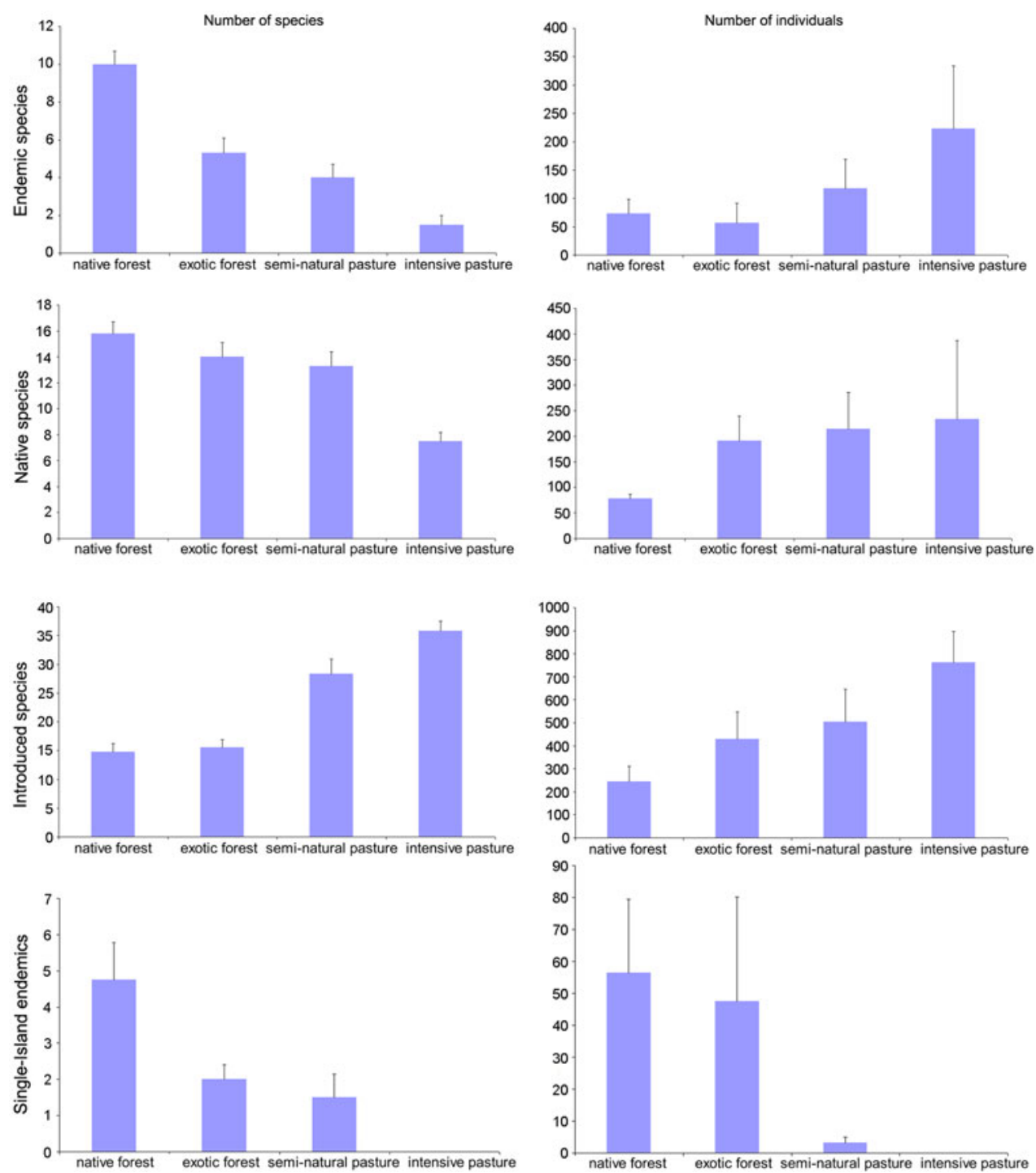

Table 2 The number of single-island endemic species and the percentage single-island endemics out of the total number of Azorean endemic species in the four habitat types on Santa Maria

\begin{tabular}{lllllc}
\hline & $\begin{array}{l}\text { Native } \\
\text { forest }\end{array}$ & $\begin{array}{l}\text { Exotic } \\
\text { forest }\end{array}$ & $\begin{array}{l}\text { Semi-natural } \\
\text { pasture }\end{array}$ & $\begin{array}{l}\text { Intensive } \\
\text { pasture }\end{array}$ & Total \\
\hline $\begin{array}{c}\text { Azorean } \\
\text { endemics }\end{array}$ & 17 & 13 & 8 & 3 & 25 \\
$\begin{array}{c}\text { Singe-island } \\
\text { endemics }\end{array}$ & 7 & 5 & 4 & 0 & 9 \\
$\%$ & 41.2 & 38.5 & 50.0 & 0.0 & 36.0 \\
\hline
\end{tabular}

In each habitat type, four $150 \mathrm{~m}$ long transects containing 30 pitfall traps were sampled

$R=0.787, P=0.001)$. The arthropod community in native forest has a larger proportion of Azorean endemic and native species compared to the other habitat types, whereas the semi-natural and intensive pasture have relatively more introduced species (Table 3 ). In addition, the species composition was also different between the four habitat types for the three species groups (ANOSIM; $R=0.823, P=0.001$ for Azorean endemic species; $R=0.597, P=0.001$ for native species; and $R=0.602$, $P=0.001$ for introduced species), suggesting that the four habitat types have different Azorean endemic, native and introduced species. All pairwise comparisons were significant as well, except for Azorean endemic species composition in natural forest vs. exotic forest (ANOSIM; $R=0.146, P=0.157$ ) and for introduced species composition in exotic forest vs. semi-natural pasture (ANOSIM; $R=0.302, P=0.1$ ).

The differences in species composition between the four habitat types were further supported by the detrended correspondence analysis (DCA). The ordination of the sites is a product of the distribution of species across the sites and the first two axes represent the two most prominent compositional gradients inherent to the data (Fig. 4). For 
Fig. 4 Sites ordination plots by DCA for a endemic, $\mathbf{b}$ native and $\mathbf{c}$ introduced species composition. In each habitat type, four $150 \mathrm{~m}$ long transects containing 30 pitfall traps were sampled. $N F$ native forest,

$E F$ exotic forest, $S N P$ seminatural pasture, $I P$ intensive pasture
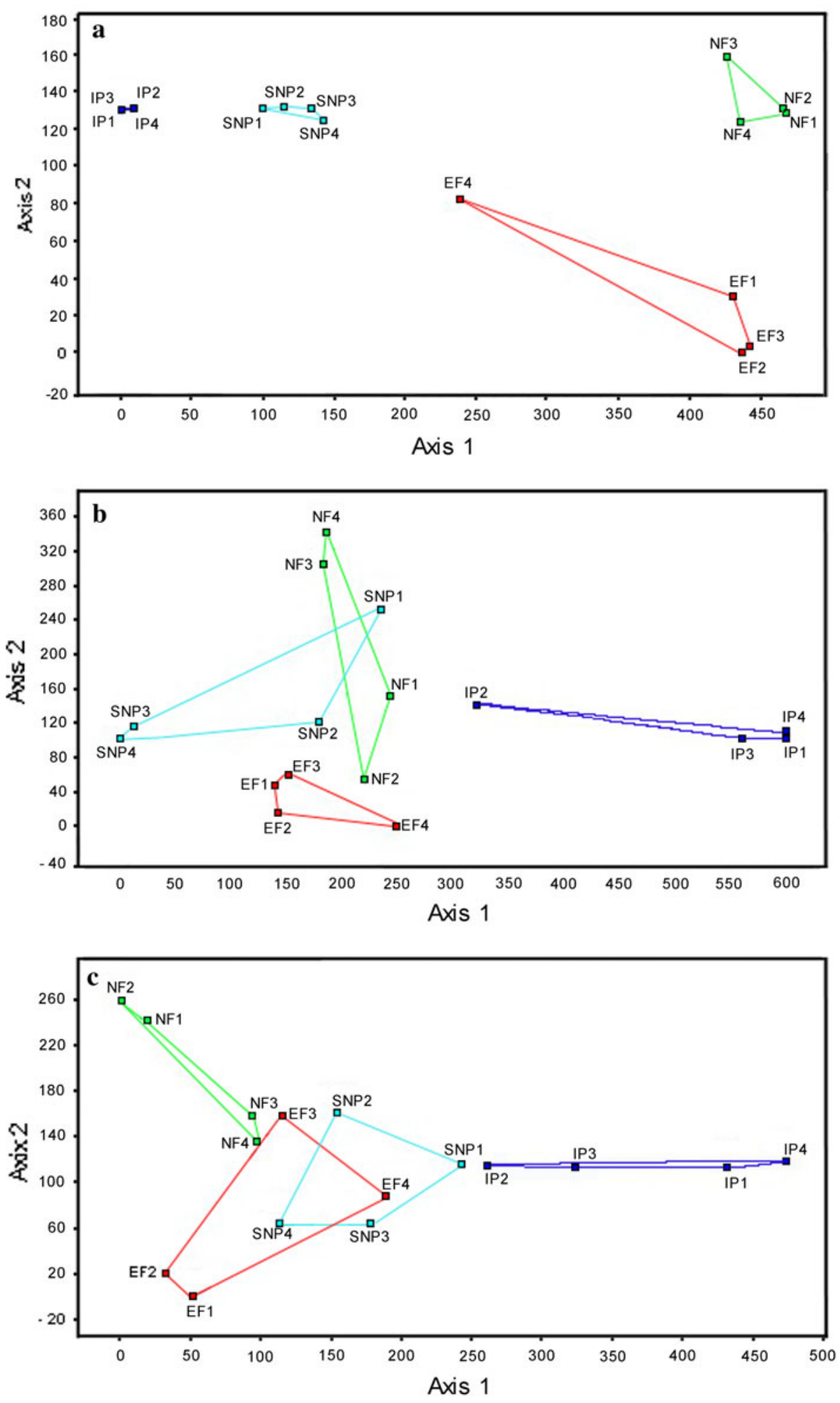

the Azorean endemic species, the habitat types were clearly clustered and each habitat type formed a separate group. For native and introduced species composition there was more overlap between the four habitat types, suggesting that these species are more uniformly spread. The first axis of the ordination separates the forests from the pastures for
Azorean endemic, native and introduced species (eigenvalues axis 1: $0.965 ; 0.972$ and 0.741 , respectively). The second axis separates the native forest from the exotic forest (eigenvalues axis 2: 0.277 for Azorean endemic species; 0.519 for native species and 0.245 for introduced species, Fig. 4). 
Table 3 The total number of Azorean endemic, native (excluding endemics) and introduced species in the four habitat types and the number and percentage of species that are unique to each habitat type

\begin{tabular}{|c|c|c|c|c|c|c|c|c|c|c|c|c|}
\hline & \multicolumn{4}{|c|}{ Azorean endemic } & \multicolumn{4}{|c|}{ Native } & \multicolumn{4}{|c|}{ Introduced } \\
\hline & $\mathrm{NF}$ & $\mathrm{EF}$ & SNP & IP & NF & $\mathrm{EF}$ & SNP & IP & $\mathrm{NF}$ & $\mathrm{EF}$ & SNP & IP \\
\hline Total & 17 & 13 & 8 & 3 & 28 & 27 & 22 & 18 & 32 & 28 & 49 & 67 \\
\hline Unique & 9 & 4 & 1 & 1 & 9 & 1 & 3 & 5 & 6 & 1 & 7 & 28 \\
\hline$\%$ Unique & 52.9 & 30.8 & 12.5 & 33.3 & 32.1 & 3.7 & 13.6 & 27.8 & 18.8 & 3.6 & 14.3 & 41.8 \\
\hline
\end{tabular}

In each habitat type, four $150 \mathrm{~m}$ long transects containing 30 pitfall traps were sampled

$N F$ native forest, $E F$ exotic forest, $S N P$ semi-natural pasture, $I P$ intensive pasture

Species uniqueness

From the 17 Azorean endemic species that are found in the native forest, nine species occur exclusively in the native forest and in none of the other habitat types (Table 3). This means that for at least $50 \%$ of the Azorean endemic species on Santa Maria, the native forest is the only place where they occur. The exotic forest has four out of 13 Azorean endemic species that are unique to this habitat type, whereas in the semi-natural pasture only one out of 8 Azorean endemics is restricted to this habitat type. There are three Azorean endemic species that occur on the intensive pasture, of which one is unique to this type of habitat.

For the native species, nine out of 28 species found in the native forest were not found outside of this habitat type, which represents about one-third of the native species found in the native forest (Table 3). In the exotic forest, just one out of 27 native species seems to occur solely in this habitat type, whereas the semi-natural pasture has three out of 22 native species that are unique. Surprisingly, the intensive pasture is home to five native species that occur exclusively in this habitat type, which is more than one-fourth of the total of 22 native species found in the intensive pastures.

For the introduced species, there is an opposite trend (Table 3). The native forest has only six introduced species restricted to this habitat type out of a total of 32 . In the exotic forest there is only one introduced species that does not occur in any of the other habitat types. The semi-natural pasture has seven out of 49 species that only occur in this habitat type. The intensive pasture has the highest proportion of unique introduced species, with 28 out of 67 species $(40 \%)$ only occurring in this habitat type.

Distance from the native forest

There was no significant correlation between the distance from the native forest and species richness and abundance when the exotic forest and semi-natural pasture were grouped together. However, when these two habitat types were analysed separately, there were some significant correlations that support the third hypothesis. In the seminatural pasture, the number of SIE species decreased with increasing distance from the native forest (Spearman correlation; $r=-1, P<0.01$; Fig. 5a). For the exotic forest, the abundance of both Azorean endemics and SIEs decreased with increasing distance from the native forest (Spearman correlation; $r=-1, P<0.01$, Fig. 5b).

\section{Discussion}

Our findings support the proposition that land use change has significantly affected arthropod species richness and abundance on Santa Maria. As hypothesised, the numbers of Azorean endemic and native species were highest in the native forest and they were lowest in the highly modified intensive pasture. In addition, the intensive pastures had the
Fig. 5 Relationship between distance to the native forest and a number of SIE species in the semi-natural pasture and b abundance of endemic and SIE species in the exotic forest. In each habitat type, four $150 \mathrm{~m}$ long transects containing 30 pitfall traps were sampled
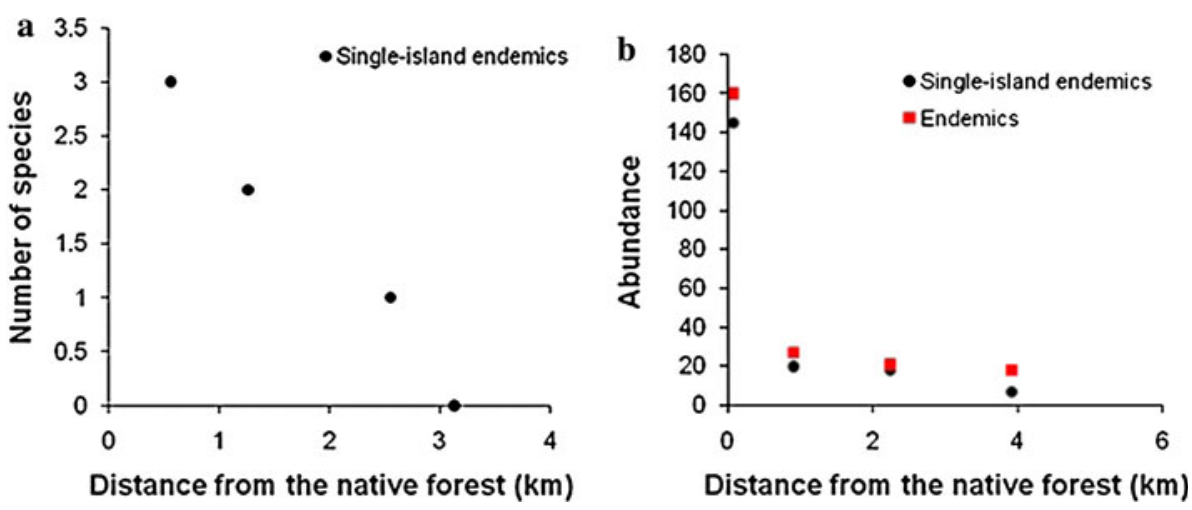
highest introduced species richness and abundance. Following some recent work confirming the relevance of native forests for the conservation of Azorean endemic arthropod biodiversity (e.g. Borges et al. 2005a, 2006, 2008; Ribeiro et al. 2005; Gaspar et al. 2008; Cardoso et al. 2009), our findings reinforce the important role of the native forest in arthropod conservation on the Azores, with 7 out of 9 sampled SIEs being found in the native forest and 50\% of the sampled Azorean endemic species being confined to this habitat type. There seems to be a gradient of land-use change effects on arthropods, where an increase in land-use intensity results in more negative impact on the indigenous (i.e. endemic and/or native) arthropod community. These results are in agreement with other studies in the Azores (Borges and Wunderlich 2008; Borges et al. 2008; Cardoso et al. 2009) and elsewhere (Driscoll 2005; Schweiger et al. 2005; Jana et al. 2006; Rainio and Niemelä 2006; Acevedo and Restrepo 2008; Schmidt et al. 2008), that have demonstrated negative effects of such land-use change for several taxa.

Although not as good habitat as the native forest, the exotic forest and semi-natural pasture performed better than the intensive pasture, which is in accordance with results obtained for Terceira Island (Cardoso et al. 2009). These two habitat types harboured higher numbers of Azorean endemics and native species and had a community composition more similar to the native forest compared to the intensive pasture. Similarly, other studies have found that habitat types other than pristine forest, such as agricultural fields and secondary forest can support certain species and help to maintain biodiversity (Burel et al. 1998; Toth and Kiss 1999; Grill et al. 2005). Our results support the notion that the quality of the matrix is important in species conservation, as suggested by several other studies (Ricketts 2001; Vandermeer and Carvajal 2001; Perfecto and Vandermeer 2002; Watson et al. 2005; Prugh et al. 2008; Muriel and Kattan 2009).

The community composition of the arthropods differed between the four habitat types, with higher proportions of Azorean endemics in the forest habitats and more introduced species in the pastures. This is in agreement with the third hypothesis. When clustering the four habitat types according to species composition for each colonisation group, the clustering was most clear for the Azorean endemic species, suggesting that the habitat types harboured different endemic species. The overlap in species composition was most obvious for introduced species, which indicates that introduced species are able to occupy several habitat types on the island and spread easily. In doing so, introduced species form one of the major threats to terrestrial biodiversity in the Azores (Martins 1993; Borges et al. 2006, 2008, 2009).

Interestingly, the total abundance of Azorean endemic species was highest on the intensive pastures and not in the native forest, which is not in accord with the first hypothesis. However, this was almost entirely the consequence of the great abundance of one beetle species, Heteroderes azoricus, of which 868 individual specimens were collected in the intensive pastures. Of the eight Azorean endemic species occurring in the semi-natural pasture, the spider Pardosa acorensis was also highly abundant, a pattern found in most of the Azorean islands (see also Borges and Wunderlich 2008; Cardoso et al. 2009). The number of Azorean endemic species inhabiting the pastures is low, yet these two generalist species are able to maintain populations with higher abundances than most endemic species in the native forest. The same pattern was found in a recent study on Terceira Island in the Azores (Cardoso et al. 2009), where these two species were found in high numbers in the pastures as well. Similar to our findings, Azorean endemic and native species richness on Terceira were also highest in the native forest and the intensive pasture had the highest number of introduced species. Cardoso et al. (2009) conclude that these two habitat types are the main drivers of the species composition of a particular site, with semi-natural pastures and exotic forests functioning as 'connector habitats' between natural forests. However, in the case of Santa Maria, exotic Cryptomeria japonica plantations seem to have a quite different role, accumulating a high density of endemic saproxylic beetles (see also below).

In addition to the endemic abundant and widespread Heteroderes azoricus and Pardosa acorensis, other endemic species are particularly important in Santa Maria, notably the nine SIE species exclusive to Santa Maria. The semi-natural pastures harboured four SIEs (Tarphius pomboi, Tarphius rufonodulosus, Catops velhocabrali, Olisthopus inclavatus), three of which are saproxylic beetle species. The exotic forest is home to five SIE saproxylic beetle species (Tarphius serranoi, Tarphius pomboi, Tarphius rufonodulosus, Catops velhocabrali, Caulotrupis parvus), of which the species Tarphius pomboi was particularly abundant. This might be explained by the fact that this species feeds on wood-inhabiting fungi and is able to benefit from the decaying wood found in the exotic forest in Santa Maria, as has been shown for other saproxylic beetle species in northern Europe (Okland et al. 1996; Kaila et al. 1997; Martikainen et al. 2000; Jonsson et al. 2005).

The fact that so many SIE forest-specialist beetles are found in both exotic forest and semi-natural pasture sites surrounding the native forest fragment of Santa Maria is a novel finding in the Azores. Patterns of endemic species distribution in other Azorean islands are not so positive, with most of the endemic species being restricted to native forest or having only sink populations in nearby human modified habitats (see Borges et al. 2008). The management practices 
in Santa Maria in both exotic Cryptomeria japonica plantations and semi-natural pastures are obviously different compared to similar habitats on the other islands. In fact, particularly in $C$. japonica plantations, the management is less intensive or even almost absent, leading to a more diverse vegetation and high density of dead wood favourable for many dead-wood and fungi-eating endemic saproxylic beetles. The $C$. japonica plantations surrounding the Pico Alto native forest fragment were planted in the 1960s to catch water from the fog and improve water collection for human use. Consequently, the past and current management of these human-modified exotic forests has a positive effect on the diversity of endemic arthropods on Santa Maria. Despite the fact that Santa Maria has only $0.2 \%$ of the total area of native forest in the Azores (Gaspar et al. 2008), it is home to 57 endemic arthropod species (ATLANTIS database consulted in July 2009), which makes up 20\% of the total number of Azorean endemic arthropod species. As such, Santa Maria can be considered as a 'hotspot' among the Azorean islands (see also Borges and Brown 1999; Borges et al. 2005a, b; Borges and Hortal 2009).

In accordance with the fourth hypothesis, our results showed also that with increasing distance from the native forest, the abundance of both Azorean endemics and SIEs decreased in the exotic forest and the number of SIE species decreased in the semi-natural pasture. Similar patterns of decreasing species numbers with increasing distance from natural forest have been found elsewhere (e.g. Klein et al. 2006). This suggests that the favorability of these two habitats is not general within the island, since their ability to support arthropods important to conservation depends on where they are located relative to the native forest. In addition, it is not clear what will be the long-term management of the $C$. japonica plantations surrounding the Pico Alto native forest fragment, casting some doubts on the successful conservation of saproxylic invertebrates on this island.

This study has some important implications for conservation management activities on Santa Maria. We clearly demonstrated the importance and uniqueness of the native forest for arthropod conservation and recommend that efforts should be made to protect the small patches of native forest that are left on the island. This small area of native forest is critical for the conservation of both archipelagic and single-island endemic species (Borges et al. 2005a). This study clearly showed that the exotic forest and semi-natural pasture are better habitats for these arthropods than the intensive pastures (see also Borges et al. 2008; Cardoso et al. 2009). Our results indicate that it would be better to replace disappearing native forest or abandoned fields with less intensively managed habitats such as exotic forest and semi-natural pasture, rather than intensive pastures (see also Cardoso et al. 2009), although conservation of the original habitats is of course by far the best option.

The species accumulation curves suggest that not all arthropod species that occur in the different habitat types have been sampled in this study, and this is particularly true for the native forest for which the accumulation curve is only just about to start levelling off. The latter is probably due to the fact that a lower number of individuals was captured in the native forest, but this should not be considered a bias. The fact that not all arthropod species have been sampled is not a problem for this study, as the aim was not to obtain a complete list of species for Santa Maria, but to compare arthropod species richness and abundance between the different habitat types. This finding does suggest that further sampling is likely to find more species on Santa Maria, especially in the native forest. Moreover, it is important that the arthropods on the Azores are the subject of long-term studies, as the effects of native habitat that has been lost already might become pronounced in the future. Due to this so-called 'extinction debt' (Tilman et al. 1994), many more arthropods might be on the brink of extinction than current studies have shown (Triantis et al. 2010).

Implications for the conservation of S. Maria endemic arthropods

A regional strategy for the long-term persistence of SIEs from S. Maria is needed. We suggest: (i) it is important to monitor the abundance of SIEs in the different habitats over the following decades following the Long-Term Ecological Research (LTER) strategy (see e.g. Pereira and Cooper 2006); (ii) removal of $P$. undulatum and other plant invaders and its progressive replacement by native woody species; (iii) in addition, pastures and forest plantations surrounding the small area on native forest at Pico Alto should retain their current low-intensity management in such a way that they will be able to support species that will otherwise be driven to extinction in the long term.

This study demonstrates that the matrix quality in the form of less intensive agricultural management is important for the conservation of rare endemic saproxylic invertebrates in the Azores. The studied native forest fragment and part of the surrounding area is now a protected area named as Santa Maria Park using the IUCN Protected Areas Management Categories System (see Borges et al. 2005a). The Pico Alto area was classified as Category IV (protected area for the management of habitats and species), which implies some restrictions on human activities. Our results support the importance of maintaining the diverse matrix surrounding Pico Alto, to ensure the 
continuing availability of wood in several stages of decay, essential for saproxylic arthropods.

Acknowledgments We are very thankful for the support in the fieldwork by the Ecoteca of St. Maria and to the Serviços de Desenvolvimento Agrário de St. Maria. We thank Fernando Pereira and João Moniz for the help with setting up the traps and collecting of the insects, and Vasiliki Orfanou and João Moniz for helping with the sorting and identification of the arthropods. Enésima Mendonça is thanked for her help in preparing the map of Santa Maria, and Kostas Triantis for giving useful comments on the introduction. This study was supported by a Huygens Scholarship Programme (HSP) grant and a VSB Foundation grant to S. S. M. and financial support in the Azores was provided by project "Consequences of land-use change on Azorean fauna and flora-the 2010 Target" (Ref: Direcção Regional da Ciência e Tecnologia M.2.1.2/I/003/2008) to P. A. V. B.

\section{Appendix 1}

See Table 4.

Table 4 Information on all transects in the four habitat types on Santa Maria

\begin{tabular}{|c|c|c|c|c|c|c|}
\hline Name & Transect & Sampled & Habitat & Longitude & Latitude & Elevation $(\mathrm{m})$ \\
\hline Pico Alto & T01 & August 1997 & Native forest & 669927 & 4094384 & 530 \\
\hline Pico Alto & T02 & August 1997 & Native forest & 669823 & 4094394 & 530 \\
\hline Pico Alto & T03 & June 2004 & Native forest & 670257 & 4094043 & 479 \\
\hline Pico Alto & T04 & June 2004 & Native forest & 670170 & 4094140 & 479 \\
\hline Aeroporto-Cabrestantes & T05 & June 2009 & Intensive pasture & 662662 & 4096328 & 43 \\
\hline Pico do Facho & T06 & June 2009 & Intensive pasture & 665588 & 4090185 & 52 \\
\hline Casas Velhas & T07 & June 2009 & Semi-natural pasture & 671945 & 4091662 & 379 \\
\hline Fonte Jordão & T08 & June 2009 & Intensive pasture & 673963 & 4090920 & 271 \\
\hline Pico Alto-L & T09 & June 2009 & Exotic forest & 670185 & 4094194 & 464 \\
\hline Cruzamento Pico Alto & $\mathrm{T} 10$ & June 2009 & Exotic forest & 670608 & 4093423 & 419 \\
\hline Pico Alto-PSN & $\mathrm{T} 11$ & June 2009 & Semi-natural pasture & 670417 & 4093748 & 482 \\
\hline Fontinhas-PSN & $\mathrm{T} 12$ & June 2009 & Semi-natural pasture & 671513 & 4092040 & 448 \\
\hline Fontinhas & $\mathrm{T} 13$ & June 2009 & Exotic forest & 671308 & 4092293 & 419 \\
\hline St. Espírito & $\mathrm{T} 14$ & June 2009 & Exotic forest & 673033 & 4091592 & 318 \\
\hline Ponta do Norte & $\mathrm{T} 15$ & June 2009 & Intensive pasture & 672741 & 4096864 & 219 \\
\hline Alto da Nascente & T16 & June 2009 & Semi-natural pasture & 669313 & 4095181 & 296 \\
\hline
\end{tabular}

Long/Lat coordinates are presented in UTMs

\section{Appendix 2}

See Table 5.

Table 5 Taxonomic list of all the species found, with the indication of the abundance of each species in the four types of land-use

\begin{tabular}{|c|c|c|c|c|c|c|c|c|c|}
\hline $\mathrm{N} / \mathrm{E} / \mathrm{I}$ & Code MF & Species & Class & Order & Family & NF & $\mathrm{EF}$ & SNP & IP \\
\hline $\mathrm{E}$ & MF134 & Gibbaranea occidentalis Wunderlich & Arachnida & Araneae & Araneidae & 3 & & 1 & \\
\hline $\mathrm{E}$ & MF17 & Pardosa acorensis Simon & Arachnida & Araneae & Lycosidae & 4 & 1 & 410 & 23 \\
\hline $\mathrm{E}$ & MF5 & Rugathodes acoreensis Wunderlich & Arachnida & Araneae & Theridiidae & & 6 & & \\
\hline $\mathrm{E}$ & MF50 & Lepthyphantes acoreensis Wunderlich & Arachnida & Araneae & Linyphiidae & 6 & & & \\
\hline $\mathrm{E}$ & MF526 & Neon acoreensis Wunderlich & Arachnida & Araneae & Salticidae & & 1 & & \\
\hline I & MF1014 & Gen. sp. & Arachnida & Araneae & Salticidae & & & & 2 \\
\hline I & MF1047 & Heliophanus kochi Simon & Arachnida & Araneae & Salticidae & & & & 4 \\
\hline I & MF1100 & Zelotes tenuis (C.L. Koch) & Arachnida & Araneae & Gnaphosidae & & & & 3 \\
\hline I & MF1071 & Chalcoscirtus infimus (Simon) & Arachnida & Araneae & Salticidae & & & & 5 \\
\hline I & MF1118 & Micaria pallipes (Lucas) & Arachnida & Araneae & Gnaphosidae & & & & 10 \\
\hline
\end{tabular}


Table 5 continued

\begin{tabular}{|c|c|c|c|c|c|c|c|c|c|}
\hline $\mathrm{N} / \mathrm{E} / \mathrm{I}$ & Code MF & Species & Class & Order & Family & NF & $\mathrm{EF}$ & SNP & IP \\
\hline I & MF122 & Clubiona terrestris Westring & Arachnida & Araneae & Clubionidae & 1 & & 6 & \\
\hline I & MF127 & Steatoda grossa (C.L. Koch) & Arachnida & Araneae & Theridiidae & 1 & & & \\
\hline I & MF133 & Metellina merianae (Scopoli) & Arachnida & Araneae & Tetragnathidae & 3 & & & \\
\hline I & MF140 & Ero furcata (Villers) & Arachnida & Araneae & Mimetidae & 1 & 1 & & \\
\hline I & MF21 & Tenuiphantes tenuis (Blackwall) & Arachnida & Araneae & Linyphiidae & 125 & 49 & 65 & 9 \\
\hline I & MF233 & Oedothorax fuscus (Blackwall) & Arachnida & Araneae & Linyphiidae & & & 378 & 664 \\
\hline I & MF234 & Erigone autumnalis Emerton & Arachnida & Araneae & Linyphiidae & & & 5 & 67 \\
\hline I & MF24 & Eperigone fradeorum (Berland) & Arachnida & Araneae & Linyphiidae & & & & 17 \\
\hline I & MF250 & Xysticus nubilus Simon & Arachnida & Araneae & Thomisidae & & & 4 & 66 \\
\hline I & MF28 & Dysdera crocata C. L. Koch & Arachnida & Araneae & Dysderidae & 12 & 5 & 7 & 25 \\
\hline I & MF330 & Meioneta fuscipalpis (C.L. Koch) & Arachnida & Araneae & Linyphiidae & & & & 32 \\
\hline I & MF333 & Ostearius melanopygius (O. P.-Cambridge) & Arachnida & Araneae & Linyphiidae & & 1 & 1 & 4 \\
\hline I & MF334 & Gen. sp. & Arachnida & Araneae & Linyphiidae & & & 2 & \\
\hline I & MF34 & Erigone atra (Blackwall) & Arachnida & Araneae & Linyphiidae & & & & 2 \\
\hline I & MF488 & Achaearanea acoreensis (Berland) & Arachnida & Araneae & Theridiidae & & 1 & 5 & 4 \\
\hline I & MF489 & Lycosoides coarctata (Dufour) & Arachnida & Araneae & Agelenidae & & & & 2 \\
\hline I & MF701 & Haplodrassus signifer (C. L. Koch) & Arachnida & Araneae & Gnaphosidae & & & & 1 \\
\hline I & MF988 & Oecobius similis Kulczynski & Arachnida & Araneae & Oecobiidae & & & & 6 \\
\hline I & MF998 & Zelotes aeneus (Simon) & Arachnida & Araneae & Gnaphosidae & & & & 38 \\
\hline I & MF688 & Clubiona genevensis L. Koch & Arachnida & Araneae & Clubionidae & & & & 30 \\
\hline $\mathrm{N}$ & MF117 & Lathys dentichelis (Simon) & Arachnida & Araneae & Dictynidae & 1 & & & \\
\hline $\mathrm{N}$ & MF2 & Tenuiphantes miguelensis Wunderlich & Arachnida & Araneae & Linyphiidae & 34 & 18 & & \\
\hline $\mathrm{N}$ & MF20 & Palliduphantes schmitzi (Kulczynski) & Arachnida & Araneae & Linyphiidae & 9 & 15 & 2 & \\
\hline $\mathrm{N}$ & MF33 & Homalenotus coriaceus (Simon) & Arachnida & Opiliones & Phalangiidae & 61 & 24 & 139 & 11 \\
\hline $\mathrm{N}$ & MF103 & Chthonius tetrachelatus (Preyssler) & Arachnida & Pseudoscorpiones & Chthoniidae & 2 & & 5 & \\
\hline $\mathrm{N}$ & MF38 & Chthonius ischnocheles (Hermann) & Arachnida & Pseudoscorpiones & Chthoniidae & 1 & 6 & & \\
\hline $\mathrm{N}$ & MF26 & Geophilus truncorum Bergsoe \& Meinert & Chilopoda & Geophilomorpha & Geophilidae & & & & 17 \\
\hline $\mathrm{N}$ & MF27 & Lithobius pilicornis pilicornis Newport & Chilopoda & Lithobiomorpha & Lithobiidae & & 1 & & \\
\hline $\mathrm{N}$ & MF1006 & Lithobius sp. & Chilopoda & Lithobiomorpha & Lithobiidae & & & & 4 \\
\hline I & MF336 & Scutigera coleoptrata (Linnaeus) & Chilopoda & Scutigeromorpha & Scutigeridae & & & & 42 \\
\hline $\mathrm{N}$ & MF468 & Haplobainosoma lusitanum Verhoeff & Diplopoda & Chordeumatida & Haplobainosomatidae & 3 & & & \\
\hline I & MF309 & Choneiulus palmatus (Nemec) & Diplopoda & Julida & Blaniulidae & 83 & & 2 & \\
\hline I & MF9 & Ommatoiulus moreletii (Lucas) & Diplopoda & Julida & Julidae & 218 & 194 & 330 & 93 \\
\hline I & MF48 & Blaniulus guttullatus (Fabricius) & Diplopoda & Julida & Blaniulidae & 305 & 101 & & \\
\hline I & MF62 & Brachyiulus pusillus (Leach) & Diplopoda & Julida & Julidae & 3 & 30 & 9 & 2 \\
\hline $\mathrm{N}$ & MF282 & Cylindroiulus propinquus (Porat) & Diplopoda & Julida & Julidae & 15 & 20 & 11 & 14 \\
\hline $\mathrm{N}$ & MF49 & Nopoiulus kochii (Gervais) & Diplopoda & Julida & Blaniulidae & 16 & 2 & & \\
\hline $\mathrm{N}$ & MF53 & Proteroiulus fuscus (Am Stein) & Diplopoda & Julida & Blaniulidae & 26 & 8 & 1 & \\
\hline $\mathrm{N}$ & MF544 & Cylindroiulus latestriatus (Curtis) & Diplopoda & Julida & Julidae & 5 & & & \\
\hline I & MF71 & Oxidus gracilis (C.L.Koch) & Diplopoda & Polydesmida & Paradoxosomatidae & 20 & 82 & 33 & 1 \\
\hline $\mathrm{N}$ & MF37 & Polydesmus coriaceus Porat & Diplopoda & Polydesmida & Polydesmidae & 19 & 510 & 40 & \\
\hline $\mathrm{N}$ & MF59 & Zetha vestita (Brullé) & Insecta & Blattaria & Polyphagidae & 32 & 10 & 35 & 9 \\
\hline $\mathrm{N}$ & MF1113 & Loboptera decipiens (Germar) & Insecta & Blattaria & Blattellidae & & & & 803 \\
\hline $\mathrm{E}$ & MF107 & Atlantocis gillerforsi Israelson & Insecta & Coleoptera & Ciidae & & 2 & & \\
\hline $\mathrm{E}$ & MF1098 & Olisthopus inclavatus Istaelson & Insecta & Coleoptera & Carabidae & & & 6 & \\
\hline $\mathrm{E}$ & MF128 & Caulotrupis parvus Israelson & Insecta & Coleoptera & Curculionidae & 6 & 1 & & \\
\hline $\mathrm{E}$ & MF138 & Athous pomboi Platia \& Borges & Insecta & Coleoptera & Elateridae & 3 & & & \\
\hline E & MF244 & Alestrus dolosus (Crotch) & Insecta & Coleoptera & Elateridae & & & & 1 \\
\hline
\end{tabular}


Table 5 continued

\begin{tabular}{|c|c|c|c|c|c|c|c|c|c|}
\hline $\mathrm{N} / \mathrm{E} / \mathrm{I}$ & Code MF & Species & Class & Order & Family & $\mathrm{NF}$ & $\mathrm{EF}$ & SNP & IP \\
\hline $\mathrm{E}$ & MF540 & Heteroderes azoricus Tarnier & Insecta & Coleoptera & Elateridae & & 2 & 42 & 868 \\
\hline $\mathrm{E}$ & MF64 & Tarphius serranoi Borges & Insecta & Coleoptera & Zopheridae & 108 & 5 & & \\
\hline $\mathrm{E}$ & MF70 & Tarphius pomboi Borges & Insecta & Coleoptera & Zopheridae & 103 & 176 & 3 & \\
\hline $\mathrm{E}$ & MF73 & Metophthalmus occidentalis Israelson & Insecta & Coleoptera & Lathridiidae & 4 & & & \\
\hline $\mathrm{E}$ & MF76 & Tarphius rufonodulosus Israelson & Insecta & Coleoptera & Zopheridae & 1 & 7 & 3 & \\
\hline $\mathrm{E}$ & MF77 & Pseudechinosoma nodosum Hustache & Insecta & Coleoptera & Curculionidae & 10 & 3 & & \\
\hline $\mathrm{E}$ & MF84 & Catops velhocabrali Blas \& Borges & Insecta & Coleoptera & Leiodidae & & 1 & 1 & \\
\hline $\mathrm{E}$ & MF85 & Tarphius depressus Gillerfors & Insecta & Coleoptera & Zopheridae & 6 & 20 & 3 & \\
\hline I & MF108 & Cryptamorpha desjardinsii (Guérin-Méneville) & Insecta & Coleoptera & Silvanidae & & 1 & 21 & \\
\hline I & MF1097 & Gen. sp. & Insecta & Coleoptera & Lyctidae & & 2 & & \\
\hline I & MF1099 & Carpophilus sp. & Insecta & Coleoptera & Nitidulidae & & & 1 & \\
\hline I & MF1101 & Gen. sp. & Insecta & Coleoptera & Cucujidae & & & & 40 \\
\hline I & MF1105 & Bruchus sp. & Insecta & Coleoptera & Chrysomelidae & & & & 2 \\
\hline I & MF1106 & Sitona $\mathrm{sp}$. & Insecta & Coleoptera & Curculionidae & & & & 1 \\
\hline I & MF1110 & Gen. sp. & Insecta & Coleoptera & Corylophidae & & & 1 & \\
\hline I & MF1111 & Gen. sp. & Insecta & Coleoptera & Curculionidae & & & 2 & 2 \\
\hline I & MF1114 & Calamosternus granarius (Linnaeus) & Insecta & Coleoptera & Aphodiidae & & & & 28 \\
\hline I & MF1117 & Gen. sp. & Insecta & Coleoptera & Chrysomelidae & & & & 2 \\
\hline I & MF1120 & Notiophilus quadripunctatus Dejean & Insecta & Coleoptera & Carabidae & & & & 1 \\
\hline I & MF113 & Typhaea stercorea (Linnaeus) & Insecta & Coleoptera & Mycetophagidae & 1 & 2 & 2 & 10 \\
\hline I & MF120 & Coccotrypes carpophagus (Hornung) & Insecta & Coleoptera & Curculionidae & 6 & & 1 & \\
\hline I & MF142 & Cilea silphoides (Linnaeus) & Insecta & Coleoptera & Staphylinidae & & 1 & & 1 \\
\hline I & MF145 & Cryptophagus sp. & Insecta & Coleoptera & Cryptophagidae & 1 & & 5 & 108 \\
\hline I & MF161 & Amara aenea (De Geer) & Insecta & Coleoptera & Carabidae & & & & 2 \\
\hline I & MF162 & Atheta amicula (Stephens) & Insecta & Coleoptera & Staphylinidae & 2 & & & \\
\hline I & MF247 & Aleochara bipustulata (Linnaeus) & Insecta & Coleoptera & Staphylinidae & & & 1 & 7 \\
\hline I & MF266 & Chaetocnema hortensis (Fourcroy) & Insecta & Coleoptera & Chrysomelidae & & & 3 & \\
\hline I & MF268 & Carpophilus sp. & Insecta & Coleoptera & Nitidulidae & & & & 1 \\
\hline I & MF271 & Anotylus sp. 2 & Insecta & Coleoptera & Staphylinidae & & & 1 & \\
\hline I & MF275 & Agonит тиеlleri mиеlleri (Herbst) & Insecta & Coleoptera & Carabidae & & & 3 & 2 \\
\hline I & MF308 & Stelidota geminata (Say) & Insecta & Coleoptera & Nitidulidae & 2 & 824 & 115 & 56 \\
\hline I & MF341 & Philonthus politus politus (Linnaeus) & Insecta & Coleoptera & Staphylinidae & & & & 1 \\
\hline I & MF342 & Cercyon sp. & Insecta & Coleoptera & Hydrophilidae & & 1 & 1 & 3 \\
\hline I & MF344 & Sitona discoideus Gyllenhal & Insecta & Coleoptera & Curculionidae & & & 1 & 10 \\
\hline I & MF386 & Sitona puberulus Reitter & Insecta & Coleoptera & Curculionidae & & & 1 & \\
\hline I & MF395 & Psylliodes marcidus (Illiger) & Insecta & Coleoptera & Chrysomelidae & & & 10 & 1 \\
\hline I & MF45 & Anisodactylus binotatus (Fabricius) & Insecta & Coleoptera & Carabidae & & & 50 & 2 \\
\hline I & MF502 & Omosita colon (Linnaeus) & Insecta & Coleoptera & Nitidulidae & & & & 1 \\
\hline I & MF51 & Paranchus albipes (Fabricius) & Insecta & Coleoptera & Carabidae & 8 & 258 & 128 & 97 \\
\hline I & MF52 & Cordalia obscura (Gravenhorst) & Insecta & Coleoptera & Staphylinidae & 1 & 1 & 6 & 6 \\
\hline I & MF523 & Sphenophorus abbreviatus (Fabricius) & Insecta & Coleoptera & Dryophthoridae & & & & 2 \\
\hline I & MF541 & Hirticomus quadriguttatus (Rossi) & Insecta & Coleoptera & Anthicidae & & & & 407 \\
\hline I & MF57 & Atheta atramentaria (Gyllenhal) & Insecta & Coleoptera & Staphylinidae & & 2 & 7 & \\
\hline I & MF570 & Meligethes aeneus (Fabricius) & Insecta & Coleoptera & Nitidulidae & & & & 1 \\
\hline I & MF61 & Epuraea biguttata (Thunberg) & Insecta & Coleoptera & Nitidulidae & 3 & 9 & 30 & \\
\hline I & MF65 & Sericoderus lateralis (Gyllenhal) & Insecta & Coleoptera & Corylophidae & & 1 & 200 & 7 \\
\hline I & MF66 & Amischa analis (Gravenhorst) & Insecta & Coleoptera & Staphylinidae & 6 & 2 & & 3 \\
\hline I & MF693 & Gen. sp. & Insecta & Coleoptera & Curculionidae & & & 1 & \\
\hline
\end{tabular}


Table 5 continued

\begin{tabular}{|c|c|c|c|c|c|c|c|c|c|}
\hline $\mathrm{N} / \mathrm{E} / \mathrm{I}$ & Code MF & Species & Class & Order & Family & $\mathrm{NF}$ & $\mathrm{EF}$ & SNP & IP \\
\hline I & MF703 & Nephus helgae Fursh & Insecta & Coleoptera & Coccinellidae & & & & 3 \\
\hline I & MF72 & Ptenidium pusillum (Gyllenhal) & Insecta & Coleoptera & Ptiliidae & 1 & 1 & 3 & \\
\hline I & MF74 & Pseudophonus rufipes (DeGeer) & Insecta & Coleoptera & Carabidae & 1 & & 2 & \\
\hline I & MF758 & Gen. sp. & Insecta & Coleoptera & Anthicidae & & 1 & & 11 \\
\hline I & MF764 & Harpalus distinguendus (Duftschmidt) & Insecta & Coleoptera & Carabidae & & & & 11 \\
\hline I & MF767 & Oligota parva Kraatz & Insecta & Coleoptera & Staphylinidae & & & 1 & . \\
\hline I & MF771 & Astenus lyonessius (Joy) & Insecta & Coleoptera & Staphylinidae & & & & . \\
\hline I & MF777 & Gen. sp. & Insecta & Coleoptera & Anthicidae & & & & 37 \\
\hline I & MF823 & Coproporus pulchellus (Erichson) & Insecta & Coleoptera & Staphylinidae & & & & \\
\hline I & MF828 & Carpophilus hemipterus (Linnaeus) & Insecta & Coleoptera & Nitidulidae & 1 & & & \\
\hline I & MF885 & Oxytelus sculptus Gravenhorst & Insecta & Coleoptera & Staphylinidae & & & 2 & 3 \\
\hline I & MF888 & Gen. sp. & Insecta & Coleoptera & Ptiliidae & & & 2 & \\
\hline I & MF89 & Tachyporus chrysomelinus (Linnaeus) & Insecta & Coleoptera & Staphylinidae & 1 & 23 & 110 & 25 \\
\hline I & MF944 & Gen. sp. & Insecta & Coleoptera & Laemophloeidae & & & & 1 \\
\hline I & MF99 & Phloeonomus sp.3 & Insecta & Coleoptera & Staphylinidae & & 3 & 2 & \\
\hline I & MF153 & Atheta sp.2 & Insecta & Coleoptera & Staphylinidae & & & 3 & \\
\hline I & MF16 & Atheta fungi (Gravenhorst) & Insecta & Coleoptera & Staphylinidae & 147 & 21 & 123 & \\
\hline I & MF354 & Orthochaetes insignis (Aubé) & Insecta & Coleoptera & Curculionidae & & & 5 & \\
\hline I & MF673 & Mecinus pascuorum (Gyllenhal) & Insecta & Coleoptera & Curculionidae & & & & 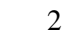 \\
\hline I & MF708 & Aridius sp. & Insecta & Coleoptera & Lathridiidae & & & 1 & \\
\hline $\mathrm{N}$ & MF102 & Pseudophloeophagus tenax (Wollaston) & Insecta & Coleoptera & Curculionidae & 3 & 6 & 1 & \\
\hline $\mathrm{N}$ & MF1086 & Gen. sp. & Insecta & Coleoptera & Curculionidae & & 1 & & 12 \\
\hline $\mathrm{N}$ & MF1104 & Rhyzobius litura (Fabricius) & Insecta & Coleoptera & Coccinellidae & & & & 11 \\
\hline $\mathrm{N}$ & MF1115 & Psilothrix viridicoerulea (Geoffroy) & Insecta & Coleoptera & Dasytidae & & & & 5 \\
\hline $\mathrm{N}$ & MF23 & Phloeonomus sp. & Insecta & Coleoptera & Staphylinidae & & 1 & & \\
\hline $\mathrm{N}$ & MF25 & Pseudophloeophagus aenopiceus (Boheman) & Insecta & Coleoptera & Curculionidae & & 1 & & \\
\hline $\mathrm{N}$ & MF262 & Rugilus orbiculatus orbiculatus (Paykull) & Insecta & Coleoptera & Staphylinidae & & 1 & 204 & \\
\hline $\mathrm{N}$ & MF68 & Sepedophilus lusitanicus (Hammond) & Insecta & Coleoptera & Staphylinidae & 1 & & & \\
\hline $\mathrm{N}$ & MF69 & Stilbus testaceus (Panzer) & Insecta & Coleoptera & Phalacridae & & & 4 & 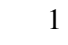 \\
\hline $\mathrm{N}$ & MF78 & Anaspis proteus (Wollaston) & Insecta & Coleoptera & Scraptiidae & & & 10 & \\
\hline $\mathrm{N}$ & MF79 & Quedius curtipennis Bernhauer & Insecta & Coleoptera & Staphylinidae & & 5 & 261 & \\
\hline $\mathrm{N}$ & MF82 & Proteinus atomarius Erichson & Insecta & Coleoptera & Staphylinidae & 2 & 4 & 5 & \\
\hline $\mathrm{N}$ & MF88 & Ocypus olens (Muller) & Insecta & Coleoptera & Staphylinidae & & 3 & & \\
\hline $\mathrm{N}$ & MF94 & Anommatus duodecimstriatus (Muller) & Insecta & Coleoptera & Bothrideridae & & 1 & & \\
\hline $\mathrm{N}$ & MF98 & Placonotus sp.1 & Insecta & Coleoptera & Laemophloeidae & & 9 & 2 & \\
\hline $\mathrm{N}$ & MF15 & Ocys harpaloides (Audinet-Serville) & Insecta & Coleoptera & Carabidae & & 23 & & \\
\hline $\mathrm{N}$ & MF691 & Otiorhynchus cribicollis Gyllenhal & Insecta & Coleoptera & Curculionidae & & 85 & 1 & 2 \\
\hline $\mathrm{N}$ & MF360 & Gen. sp. & Insecta & Coleoptera & Corylophidae & & & & 11 \\
\hline I & MF352 & Euborellia annulipes (Lucas) & Insecta & Dermaptera & Anisolabididae & 18 & 89 & 246 & 741 \\
\hline I & MF56 & Forficula auricularia Linnaeus & Insecta & Dermaptera & Forficulidae & 2 & 7 & 21 & 9 \\
\hline $\mathrm{E}$ & MF8 & Aphrodes hamiltoni Quartau \& Borges & Insecta & Hemiptera & Cicadellidae & 30 & & & \\
\hline $\mathrm{E}$ & MF925 & Cixius azomariae Remane \& Asche & Insecta & Hemiptera & Cixiidae & 3 & & & \\
\hline I & MF155 & Pseudacaudella rubida (Borner) & Insecta & Hemiptera & Aphididae & 2 & & & \\
\hline I & MF335 & Rhopalosiphum insertum (Walker) & Insecta & Hemiptera & Aphididae & & & 1 & \\
\hline I & MF501 & Loricula coleoptrata (Fallén) & Insecta & Hemiptera & Microphysidae & & & & 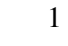 \\
\hline I & MF521 & Brachysteles parvicornis (A. Costa) & Insecta & Hemiptera & Anthocoridae & & & & 23 \\
\hline I & MF818 & Dysaphis plantaginea (Passerini) & Insecta & Hemiptera & Aphididae & & & 1 & 1 \\
\hline I & MF676 & Microplax plagiata (Fieber) & Insecta & Hemiptera & Lygaeidae & & & & 119 \\
\hline
\end{tabular}


Table 5 continued

\begin{tabular}{|c|c|c|c|c|c|c|c|c|c|}
\hline $\mathrm{N} / \mathrm{E} / \mathrm{I}$ & Code MF & Species & Class & Order & Family & $\mathrm{NF}$ & $\mathrm{EF}$ & SNP & IP \\
\hline I & MF926 & Anoscopus albifrons (Linnaeus) & Insecta & Hemiptera & Cicadellidae & 2 & & 54 & 45 \\
\hline $\mathrm{N}$ & MF1119 & Triatoma rubrofasciata (De Geer) & Insecta & Hemiptera & Reduviidae & & & & 1 \\
\hline $\mathrm{N}$ & MF124 & Cyphopterum adcendens (Herr.-Schaff.) & Insecta & Hemiptera & Flatidae & 4 & & & \\
\hline $\mathrm{N}$ & MF232 & Acyrthosiphon pisum Harris & Insecta & Hemiptera & Aphididae & & & 11 & \\
\hline $\mathrm{N}$ & MF254 & Megamelodes quadrimaculatus (Signoret) & Insecta & Hemiptera & Delphacidae & & & 64 & \\
\hline $\mathrm{N}$ & MF326 & Buchananiella continua (White) & Insecta & Hemiptera & Anthocoridae & 1 & & & \\
\hline $\mathrm{N}$ & MF60 & Rhopalosiphonimus latysiphon (Davidson) & Insecta & Hemiptera & Aphididae & 8 & 1 & 20 & \\
\hline $\mathrm{N}$ & MF83 & Plinthisus brevipennis (Latreille) & Insecta & Hemiptera & Lygaeidae & 1 & 3 & 34 & \\
\hline $\mathrm{N}$ & MF890 & Euscelidius variegatus (Kirschbaum) & Insecta & Hemiptera & Cicadellidae & & & & 6 \\
\hline $\mathrm{N}$ & MF101 & Geotomus punctulatus (Costa) & Insecta & Hemiptera & Cydnidae & 2 & & & 6 \\
\hline $\mathrm{N}$ & MF1096 & Gen. sp. & Insecta & Hemiptera & Lygaeidae & & 2 & & \\
\hline $\mathrm{N}$ & MF118 & Scolopostethus decoratus (Hahn) & Insecta & Hemiptera & Lygaeidae & 38 & 1 & & \\
\hline $\mathrm{N}$ & MF119 & Gen. sp. & Insecta & Hemiptera & Coccidae & 1 & & & \\
\hline $\mathrm{N}$ & MF132 & Gen. sp. & Insecta & Hemiptera & Coccidae & 1 & & & \\
\hline $\mathrm{N}$ & MF156 & Gen. sp. & Insecta & Hemiptera & Coccidae & 8 & & 6 & \\
\hline $\mathrm{N}$ & MF54 & Gen. sp. & Insecta & Hemiptera & Margarodidae & 10 & & & \\
\hline $\mathrm{N}$ & MF58 & Gen. sp. & Insecta & Hemiptera & Coccidae & 3 & & & \\
\hline $\mathrm{E}$ & MF12 & Cyclophora pupillaria granti Prout & Insecta & Lepidoptera & Geometridae & 2 & & & \\
\hline $\mathrm{E}$ & MF130 & Brachmia infuscatella Rebel & Insecta & Lepidoptera & Gelechiidae & 1 & & & \\
\hline $\mathrm{E}$ & MF19 & Argyresthia atlanticella Rebel & Insecta & Lepidoptera & Yponomeutidae & 3 & & & \\
\hline $\mathrm{E}$ & MF90 & Ascotis fortunata azorica Pinker & Insecta & Lepidoptera & Geometridae & 1 & & & \\
\hline I & MF1 & Gen. sp. & Insecta & Lepidoptera & Tortricidae & & 6 & & \\
\hline I & MF918 & Blastobasis sp. 3 & Insecta & Lepidoptera & Blastobasidae & 1 & & & \\
\hline $\mathrm{N}$ & MF10 & Mythimna unipuncta (Haworth) & Insecta & Lepidoptera & Noctuidae & 3 & 2 & 2 & 16 \\
\hline $\mathrm{N}$ & MF126 & Chrysodeixis chalcites (Esper) & Insecta & Lepidoptera & Noctuidae & 1 & & & \\
\hline $\mathrm{N}$ & MF220 & Noctua pronuba (Linnaeus) & Insecta & Lepidoptera & Noctuidae & & & 1 & \\
\hline $\mathrm{N}$ & MF365 & Gen. sp. & Insecta & Lepidoptera & Pyralidae & 1 & & & \\
\hline I & MF123 & Gryllus bimaculatus (De Geer) & Insecta & Orthoptera & Gryllidae & 2 & & & 3 \\
\hline I & MF245 & Eumodicogryllus bordigalensis (Latreille) & Insecta & Orthoptera & Gryllidae & & & & 38 \\
\hline $\mathrm{N}$ & MF319 & Gen. sp. & Insecta & Orthoptera & Gryllidae & & & & 1 \\
\hline $\mathrm{E}$ & MF184 & Elipsocus azoricus Meinander & Insecta & Psocoptera & Elipsocidae & & 1 & & \\
\hline $\mathrm{N}$ & MF121 & Ectopsocus briggsi McLachlan & Insecta & Psocoptera & Ectopsocidae & 1 & & & \\
\hline $\mathrm{N}$ & MF36 & Lachesilla greeni (Pearman) & Insecta & Psocoptera & Lachesillidae & 1 & & & \\
\hline I & MF135 & Nesothrips propinquus (Bagnall) & Insecta & Thysanoptera & Phlaeothripidae & 1 & & & \\
\hline
\end{tabular}

In the first column $E$ endemic from the Azores, $I$ introduced species, $N$ native non-endemic. Land-uses are coded as follows: $N F$ native forest, $E F$ exotic forest, $S N P$ semi-natural forest, $I P$ intensive pasture

\section{Appendix 3}

See Table 6.

Table 6 Completeness index (observed number of species divided by the expected number of species) for the four habitat types (four transects per habitat, each transect containing 30 pitfall traps)

\begin{tabular}{lcccc}
\hline & Native forest & Exotic forest & Semi-natural pasture & Intensive pasture \\
\hline Observed nr of species & 81 & 69 & 82 & 95 \\
Expected nr of species & 108.8 & 92.8 & 103.8 & 116.8 \\
Completeness Index & 0.74 & 0.74 & 0.79 & 0.81 \\
\hline
\end{tabular}

The expected number of species was calculated using a first-order Jack-knife estimator 


\section{References}

Abdel-Monem AA, Fernandez LA, Boone GM (1975) K-Ar ages from the eastern Azores group (Santa Maria, São Miguel and the Formigas Islands). Lithos 8:247-254

Acevedo MA, Restrepo C (2008) Land-cover and land-use change and its contribution to the large-scale organization of Puerto Rico's bird assemblages. Diversity Distrib 14:114-122

Bhagwat SA, Willis KJ, Birks HJB, Whittaker RJ (2008) Agroforestry: a refuge for tropical biodiversity? Trends Ecol Evol 23:261-267

Borges PAV, Brown VK (1999) Effect of island geological age on the arthropod species richness of Azorean pastures. Biol J Linn Soc 66:373-410

Borges PAV, Brown VK (2003) Estimating species richness of arthropods in Azorean pastures: the adequacy of suction sampling and pitfall trapping. Graellsia 59:5-22

Borges PAV, Hortal J (2009) Time, area and isolation: factors driving the diversification of Azorean arthropods. J Biogeogr 36:178191

Borges PAV, Wunderlich J (2008) Spider biodiversity patterns and their conservation in the Azorean archipelago, with description of new taxa. Syst Biodivers 6:249-282

Borges PAV, Serrano ARM, Quartau JA (2000) Ranking the Azorean Natural Forest Reserves for conservation using their endemic arthropods. J Insect Conserv 4:129-147

Borges PAV, Aguiar C, Amaral J, Amorim IR, André G, Arraiol A, Baz A, Dinis F, Enghoff H, Gaspar C, Ilharco F, Mahnert V, Melo C, Pereira F, Quartau JA, Ribeiro S, Ribes J, Serrano ARM, Sousa AB, Strassen RZ, Vieira L, Vieira V, Vitorino A, Wunderlich J (2005a) Ranking protected areas in the Azores using standardized sampling of soil epigean arthropods. Biodivers Conserv 14:2029-2060

Borges PAV, Cunha R, Gabriel R, Martins AF, Silva L, Vieira V, Dinis F, Lourenço P, Pinto N (2005b) Description of the terrestrial Azorean biodiversity. In: Borges PAV, Cunha R, Gabriel R, Martins AMF, Silva L, Vieira V (eds) A list of the terrestrial fauna (Mollusca and Arthropoda) and flora (Bryophyta, Pteridophyta and Spermatophyta) from the Azores. Direcção Regional de Ambiente and Universidade dos Açores, Horta, Angra do Heroísmo and Ponta Delgada, pp 21-68

Borges PAV, Lobo JM, de Azevedo EB, Gaspar C, Melo C, Nunes LV (2006) Invasibility and species richness of island endemic arthropods: a general model of endemic vs. exotic species. J Biogeogr 33:169-187

Borges PAV, Ugland KI, Dinis FO, Gaspar C (2008) Insect and spider rarity in an oceanic island (Terceira, Azores): true rare and pseudo-rare species. In: Fattorini S (ed) Insect ecology and conservation. Research Signpost, Kerala, pp 47-70

Borges PAV, Amorim IR, Cunha R, Gabriel R, Martins AF, Silva L, Costa A, Vieira V (2009) Azores. In: Gillespie R, Clague D (eds) Encyclopedia of Islands. University of California Press, California, pp 70-75

Brook BW, Sodhi NS, Ng PKL (2003) Catastrophic extinctions follow deforestation in Singapore. Nature 424:420-423

Brooks T, Balmford A (1996) Atlantic forest extinctions. Nature 380:115

Brooks TM, Pimm SL, Collar NJ (1997) Deforestation predicts the number of threatened birds in insular Southeast Asia. Conserv Biol 11:382-394

Brooks TM, Tobias J, Balmford A (1999a) Deforestation and bird extinctions in the Atlantic Forest. Anim Conserv 2:211-222

Brooks TM, Pimm SL, Kapos V, Ravilious C (1999b) Threat from deforestation to montane and lowland birds and mammals in insular South-east Asia. J Anim Ecol 68:1061-1078
Brooks TM, Mittermeier RA, Mittermeier CG, da Fonseca GAB, Rylands AB, Konstant WR, Flick P, Pilgrim J, Oldfield S, Magin J, Hilton-Tailor C (2002) Habitat loss and extinction in the hotspots of biodiversity. Conserv Biol 16:909-923

Bruner AG, Gullison RE, Rice RE, da Fonseca GAB (2001) Effectiveness of parks in protecting tropical biodiversity. Science 291:125-128

Burel F, Baudry J, Butet A, Clergeau P, Delettre Y, Le Coeur D, Dubs F, Morvan N, Paillat G, Petit S, Thenail C, Brunel E, Lefeuvre JC (1998) Comparative biodiversity along a gradient of agricultural landscapes. Acta Oecol 19:47-60

Cardoso P, Aranda SC, Lobo JM, Dinis F, Gaspar C, Borges PAV (2009) A spatial scale assessment of habitat effects on arthropod communities of an oceanic island. Acta Oecol 35:590-597

Chape S, Harrison J, Spalding M, Lysenko I (2005) Measuring the extent and effectiveness of protected areas as an indicator for meeting global biodiversity targets. Philos Trans R Soc Biol Sci 360:443-455

Clarke KR (1993) Non-parametric multivariate analyses of changes in community structure. Aust J Ecol 18:117-143

Cowlishaw G (1999) Predicting the pattern of decline of African primate diversity: an extinction debt from historical deforestation. Conserv Biol 13:1183-1193

Daily GC, Ehrlich PR, Sánchez-Azofeifa GA (2001) Countryside biogeography: use of human-dominated habitats by the avifauna of southern Costa Rica. Ecol Appl 11:1-13

Daily GC, Ceballos G, Pachego J, Suzán G, Sánchez-Azofeifa A (2003) Countryside biogeography of neotropical mammals: conservation opportunities in agricultural landscapes of Costa Rica. Conserv Biol 17:1814-1826

Driscoll DA (2005) Is the matrix a sea? Habitat specificity in a naturally fragmented landscape. Ecol Entomol 30:8-16

DROTRH (2008) Carta de ocupação do solo da região Autónoma dos Açores-projecto SUEMAC. Secretaria Regional do Ambiente. Direcção Regional do Ordenamento do território e dos Recursos Hídricos, Ponta Delgada

Foley JA, DeFries R, Asner GP, Barford C, Bonan G, Carpenter SR, Chapin FS, Coe MT, Daily GC, Gibbs HK, Helkowski JH, Holloway T, Howard EA, Kucharik CJ, Monfreda C, Patz JA, Prentice IC, Ramankutty N, Snyder PK (2005) Global consequences of land use. Science 309:570-574

Gascon C, Lovejoy TE, Bierregaard RO Jr, Malcolm JR, Stouffer PC, Vasconcelos HL, Laurance WF, Zimmerman B, Tocher M, Borges S (1999) Matrix habitat and species richness in tropical forest remnants. Biol Cons 91:223-229

Gaspar C, Borges PAV, Gaston KJ (2008) Diversity and distribution of arthropods in native forests of the Azores Archipelago. Arquipélago, Life Marin Sci 25:1-30

Grelle CEV, Alves MAS, Bergallo HG, Geise L, Rocha CFD, Van Sluys M, Caramaschi U (2005) Prediction of threatened tetrapods based on the species-area relationship in Atlantic Forest, Brazil. J Zool Soc Lond 265:359-364

Grill A, Knoflach B, Cleary DFR, Kati V (2005) Butterfly, spider, and plant communities in different land-use types in Sardinia, Italy. Biodivers Conserv 14:1281-1300

Hanski I (1998) Metapopulation dynamics. Nature 396:41-49

Hanski I, Koivulehto H, Cameron A, Rahagalala P (2007) Deforestation and apparent extinctions of endemic forest beetles in Madagascar. Biol Lett 3:344-347

Helm A, Hanski I, Pärtel M (2006) Slow response of plant species richness to habitat loss and fragmentation. Ecol Lett 9:72-77

Henderson PA, Seaby RMH (2007) Community Analysis Package 4.0. Pisces Conservation Ltd. Available via www.pisces-conservation. com 
Heywood VN, Mace GM, May RM, Stuart SN (1994) Uncertainties in extinction rates. Nature 368:105

Hortal J, Borges PAV, Gaspar C (2006) Evaluating the performance of species richness estimators: sensitivity to sample grain size. J Anim Ecol 75:274-287

Hughes JB, Daily GC, Ehrlich PR (2002) Conservation of tropical forest birds in countryside habitats. Ecol Lett 5:121-129

Jana G, Misra KK, Bhattacharya T (2006) Diversity of some insect fauna in industrial and non-industrial areas of West Bengal, India. J Insect Conserv 10:249-260

Janzen DH (1986) The future of tropical ecology. Ann Rev Ecol Syst 17:305-324

Jonsson BG, Kruys N, Ranius T (2005) Ecology of species living on dead wood-lessons for dead wood management. Silva Fenn 39:289-309

Kaila L, Martikainen P, Punttila P (1997) Dead trees left in clear-cuts benefit saproxylic Coleoptera adapted to natural disturbances in boreal forest. Biodivers Conserv 6:1-18

Klein AM, Steffan-Dewenter I, Tscharntke T (2006) Rain forest promotes trophic interactions and diversity of trap-nesting Hymenoptera in adjacent agroforestry. J Anim Ecol 75:315-323

MacArthur RH, Wilson EO (1963) An equilibrium theory of insular zoogeography. Evolution 17:373-387

MacArthur RH, Wilson EO (1967) The theory of island biogeography. Princeton University Press, Princeton

Margules CR, Pressey RL (2000) Systematic conservation planning. Nature 405:243-253

Martikainen P, Siitonen J, Punttila P, Kaila L, Rauh J (2000) Species richness of Coleoptera in mature managed and old-growth boreal forests in southern Finland. Biol Conserv 94:199-209

Martins AMF (1993) The Azores-Westernmost Europe: where evolution can be caught red-handed. Bol Mus Mun Funchal 2:181-198

Muriel SB, Kattan GH (2009) Effects of patch size and type of coffee matrix on Ithomiine butterfly diversity and dispersal in cloudforest fragments. Conserv Biol 23:948-956

Myers N (1992) The primary source: tropical forests and our future. W.W. Norton, New York

Okland B, Bakke A, Hagvar S, Kvamme T (1996) What factors influence the diversity of saproxylic beetles? A multiscaled study from a spruce forest in southern Norway. Biodivers Conserv 5:75-100

Oksanen J, Minchin PR (1997) Instability of ordination results under changes in input data order: explanations and remedies. J Veg Sci 8:447-454

Pereira HM, Cooper HD (2006) Towards the global monitoring of biodiversity change. Trends Ecol Evol 21:123-129

Perfecto I, Vandermeer J (2002) Quality of agroecological matrix in a tropical montane landscape: ants in coffee plantations in southern Mexico. Conserv Biol 16:174-182

Pimm SL, Russell GJ, Gittleman JL, Brooks TM (1995) The future of biodiversity. Science 269:347-350

Prugh LR, Hodges KE, Sinclair ARE, Brashares JS (2008) Effect of habitat area and isolation on fragmented animal populations. Proc Natl Acad Sci 105:20770-20775

Rainio J, Niemelä J (2006) Comparison of carabid beetle (Coleoptera: Carabidae) occurrence in rain forest and human-modified sites in south-eastern Madagascar. J Insect Conserv 10:219-228
Ramankutty N, Foley JA (1999) Estimating historical changes in global land cover: croplands from 1700 to 1992. Glob Biochem Cycles 13:997-1027

Ribeiro SP, Borges PAV, Gaspar C, Melo C, Serrano ARM, Amaral J, Aguiar C, André G, Quartau JA (2005) Canopy insect herbivores in the Azorean Laurisilva forests: key host plant species in a highly generalist insect community. Ecography 28:315-330

Ricketts TH (2001) The matrix matters: effective isolation in fragmented landscapes. Am Nat 158:87-99

Rodrigues ASL, Andelman SJ, Bakarr MI, Boitani L, Brooks TM, Cowling RM, Fishpool LDC, da Fonseca GAB, Gaston KJ, Hoffmann M, Long JS, Marquet PA, Pilgrim JD, Pressey RL, Schipper J, Sechrest W, Stuart SN, Underhill LG, Waller RW, Watts MEJ, Yan X (2004) Effectiveness of the global protected area network in representing species diversity. Nature 428:640-643

Rosenzweig ML (2003) Reconciliation ecology and the future of species diversity. Oryx 37:194-205

Schmidt MH, Thies C, Nentwig W, Tscharntke T (2008) Contrasting responses of arable spiders to the landscape matrix at different spatial scales. J Biogeogr 35:157-166

Schweiger O, Maelfait JP, Van Wingerden W, Hendrickx F, Billeter R, Speelmans M, Augenstein I, Aukema B, Aviron S, Bailey D, Bukacek R, Burel F, Diekötter T, Dirksen J, Frenzel M, Herzog F, Liira J, Roubalova M, Bugter R (2005) Quantifying the impact of environmental factors on arthropod communities in agricultural landscapes across organizational levels and spatial scales. J Appl Ecol 42:1129-1139

Sekercioglu CH, Ehrlich PR, Daily GC, Aygen D, Goehring D, Sandi RF (2002) Disappearance of insectivorous birds from tropical forest fragments. Proc Natl Acad Sci 99:263-267

Tilman D, May RM, Lehman CL, Nowak MA (1994) Habitat destruction and the extinction debt. Nature 371:65-66

Tilman D, Fargione J, Wolff B, D'Antonio C, Dobson A, Howarth R, Schindler D, Schlesinger WH, Simberloff D, Swackhamer D (2001) Forecasting agriculturally driven global environmental change. Science 292:281-284

Toth F, Kiss J (1999) Comparative analyses of epigeic spider assemblages in northern Hungarian winter wheat fields and their adjacent margins. J Arachnol 27:241-248

Triantis KA, Borges PAV, Ladle RJ, Hortal J, Gaspar C, Dinis F, Mendonça E, Silveira LMA, Gabriel R, Cardoso P, Melo C, Santos AMC, Amorim IR, Ribeiro SP, Serrano ARM, Quartau JA, Whittaker RJ (2010) Extinction debt on oceanic islands. Ecography 33:285-294

Vandermeer J, Carvajal R (2001) Metapopulation dynamics and the quality of the matrix. Am Nat 158:211-220

Vitousek PM, Mooney HA, Lubchenco J, Melillo JM (1997) Human domination of Earth's ecosystems. Science 277:494-499

Watson JEM, Whittaker RJ, Freudenberger D (2005) Bird community responses to habitat fragmentation: how consistent are they across landscapes? J Biogeogr 32:1353-1370

Whittaker RJ, Fernández-Palacios JM (2007) Island biogeography: ecology, evolution, and conservation, 2nd edn. Oxford University Press, Oxford

Wiens J (2007) The dangers of black-and-white conservation. Conserv Biol 21:1371-1372

Wilson EO (1992) The diversity of life. Harvard University Press, Cambridge 